\title{
Evaluation of the possible Immunomodulatory and Neuroprotective effects of $y$-irradiated basil (Ocimum basilicum) against arsenic toxicity in rats
}

Nadia N. Osman

Department of Biochemistry, King Abdulaziz University, Jeddah, Saudi Arabia. Department of Food Irradiation Research, National Centre for Radiation Research and Technology, Cairo, Egypt

Batoul S Amjad ( $\sim$ batoulamjad@gmail.com )

King Abdulaziz University https://orcid.org/0000-0002-1455-4712

Aishah H. Ghazwani

Department of Biochemistry, King Abdulaziz University, Jeddah, Saudi Arabia

Khadijah S. Balamash

Department of Biochemistry, King Abdulaziz University, Jeddah, Saudi Arabia

Research

Keywords: Basil, Gamma irradiation, Arsenic, Hematology, Inflammation, Immune system, Brain.

Posted Date: August 4th, 2020

DOI: https://doi.org/10.21203/rs.3.rs-38326/v1

License: (c) (i) This work is licensed under a Creative Commons Attribution 4.0 International License. Read Full License 


\section{Abstract}

In view of the widespread incidence of arsenic poisoning around the world, it was necessary to study this phenomenon and analyze it to find out how to treat it through the application of alternative medicine, which has spread its use significantly in the world using herbs and plants. Gamma irradiation as a phytosanitary treatment of food and herbal materials is increasingly recognized throughout the world by improving their hygienic quality. The aims of this study to evaluate the therapeutic effect of raw or irradiated basil on rats exposed to arsenic toxicity. Basil was irradiated by gamma rays at dose $10 \mathrm{KGy}$. Forty-eight adult Wistar albino rats were divided into six groups as follows group-1: Control group, group2: received $400 \mathrm{mg} / \mathrm{kg}$ of aqueous extract of basil, group-3: received $400 \mathrm{mg} / \mathrm{kg}$ of aqueous extract of irradiated basil, group- 4: received $10 \mathrm{mg} / \mathrm{kg}$ of sodium arsenate solution, group- 5 : received $10 \mathrm{mg} / \mathrm{kg}$ of sodium arsenate solution and $400 \mathrm{mg} / \mathrm{kg}$ of aqueous extract of basil, and group- 6 : received $10 \mathrm{mg} / \mathrm{kg}$ of sodium arsenate solution and $400 \mathrm{mg} / \mathrm{kg}$ of aqueous extract of irradiated basil. At the end of the experiment ( 5 weeks), the rats were sacrificed, blood and brain tissue samples were subjected to estimate of the following: CBC, inflammatory markers (CRP, TNF-a, and IL6), immunoglobulin markers (IgA, IgG, $\lg M)$, and the levels of oxidative stress and antioxidant in brain tissue (MDA, CAT, SOD, and GSH). The results showed a rise in the antioxidant of basil after the irradiation process. The arsenic caused a significant decreased in levels of HB, RBC, LYM, NEU and PLT, while the increased levels of WBC and reticulocyte count as compared to the control group. Also, the rats exposed to arsenic showed a significant increase in inflammatory markers, immunoglobulin markers in serum, and oxidative stress accompanied with significant decreased in antioxidant in the brain. In contrast, the administration of basil extract along with arsenic was a helpful factor in alleviation of these side effects. In conclusion, our

findings showed that the irradiation process enhanced antioxidants in basil plants. Furthermore, basil has ability to attenuated arsenic toxicity.

\section{Introduction}

Arsenic is a toxic substance that occurs naturally and is found in water, rock soil and many foods (Duker et al., 2018). Arsenic toxicity affects millions of people in different parts of the world through the ingestion of arsenic-contaminated drinking water and food (Huq et al., 2006; Flanagan, Johnston and Zheng, 2012). In recent years, arsenic toxicity has created significant public concern (Duker et al., 2018). It has no taste or smell, which makes it particularly hazardous, so you can be exposed to it without knowing it (ATSDR, 2017). So, the increasing presence of an amount of arsenic in the environment present major risks, as exposure through inhalation, ingestion and dermal contact can cause various adverse effects on health (Vimercati et al., 2017). From these adverse health effects, the disorders of the nervous system (Mochizuki et al., 2019), immune system (Tutkun et al., 2019), digestive system (Chiocchetti, Vélez and Devesa, 2018), and respiratory system (Zhao et al., 2019). To treat these disorders has suggesting used complementary and alternative medicine (CAM) that may be as helpful.

The National Center for CAM (NCCAM) describes (complementary and alternative medicine) as a category of healthcare and medical systems $(\mathrm{NCCIH}, 2018)$. A systemic review conducted by Eardley et 
al. (2012) found that, for many reasons, people are using CAM, including its availability, perceived health, and disease prevention. As one of the main forms of CAM is herbal medicines, which uses parts of a plant or whole plants to avoid and cure diseases (Bent, 2008; Pan et al., 2014). The herbal medicinal products are characterized by the presence of complex chemical compounds responsible for the pharmacological activities that contribute to health benefits (Bent, 2008). Basil plants considered from herbal medicine that has eminence value as a cure for various diseases (Patel et al., 2018).

Basil (Ocimum basilicum L.) is an herbaceous and aromatic plant worldwide cultivated which belongs to the Lamiaceae family (Jakovljević et al., 2016). It has several therapeutic properties including antioxidant, anti-aging, anticancer, antiviral, antimicrobial, anti-genotoxic, and anti-inflammatory (Sakr and Al-Amoudi, 2012; Shirazi et al., 2014). Studies have shown many pharmacological effects for basil in several diseases such as liver fibrosis (Alomar and Al-Attar, 2019), diabetes mellitus (Widjaja and Rusdiana, 2019), asthma (Eftekhar et al., 2019), anemia (Zangeneh et al., 2019), and cerebral injury (Singh, Krishan and Shri, 2018). Based on the pharmacological and therapeutic properties, basil has played an important role in both traditional pharmaceutical products and contemporary pharmacological and clinical science (Shirazi et al., 2014). But there may be concerns about the use of herbs, which is that herbs are susceptible often to contamination during processing or storage by micro-organisms and insect pests. This leads to shortens their shelf life and triggering serious illness in some cases, particularly if the herbs contaminated with Salmonella and Staphylococcus aureus (Chatterjee et al., 2016). Thus, herbs should be subjected to sterilization or microbial treatment before use.

There are various techniques for the decontamination of medicinal plants, including irradiation (Garg and Gupta, 2016). This is a physical process that applies high-energy ionizing radiation to the plants in order to enhance their safety and shelf-life (Byun et al., 1999; SádECká, 2007; Alothman, Bhat and Karim, 2009). In particular, gamma irradiation seemed to be the best way to decontaminate herbs from microbes without triggering quality changes (Lee, Lee and Kim, 2005). As the absorbed energy of radiation can break the bonds of DNA molecules in microorganisms present in the product and inactivates certain enzymes, this greatly reduced its damaging impact on products. Not only microorganisms are destroyed, but even gametes, insects and parasites are prevented from reproducing, resulting in various preservative effects (Farkas, 2006). Moreover, irradiation serves as a safe technique in food processing supported by many internationally recognized organizations, where joint (Food and Agriculture Organization/ International Atomic Energy Agency/World Health Organization) Expert Committee on the Wholesomeness of Irradiation of Food has ruled that food subject to low irradiation dosage (up to $10 \mathrm{kGy}$ ) is safe and not need any testing of toxicology (Wen et al., 2006).

The present study was therefore designed to evaluate the possible immunomodulatory and antiinflammatory effects of raw and irradiated basil (Ocimum basilicum) against arsenic toxicity in rats.

\section{Materials And Methods}

\subsection{Materials}




\subsubsection{Chemicals and kits}

Sodium arsenate was obtained from British Drug Houses (BDH) chemical company, England, UK. Diethyl ether was obtained from Sigma-Aldrich company, Louis, USA. Kits for assays of immunoglobulin G (IgG), immunoglobulin M (IgM), immunoglobulin A ( $\operatorname{lgA}$ ), tumor necrosis factor-alpha (TNFa), interleukin (IL-6), C- reactive protein (CRP), superoxide dismutase (SOD), glutathione (GSH), catalase (CAT) and malondialdehyde (MDA) were obtained from Abcam Chemical Company, Cambridge, UK. kits for assay Total capacity antioxidant were obtained from Cell Biolabs company, California, USA. Kits assay protein concentration in tissues (PierceTM BCA Protein Kit) was obtained from Thermo Fisher Scientific company, Waltham, US.

\subsubsection{Plant material}

The basil (Ocimum basilicum) leaves were purchased from the local traditional market in Jeddah, Saudi Arabia.

\subsubsection{Gamma Irradiation treatment}

The samples of dry basil powder were irradiated with $10 \mathrm{KGy}$ of gamma rays after the leaves were transferred into polyethylene bags, using a Cobalt-60 source at a dose rate of $4.75 \mathrm{KGy} / \mathrm{h}$ at the National Centre for Radiation Research and Technology (NCRRT), Nasr City, Cairo, Egypt.

\subsubsection{Experimental animals}

The study will be carried out using adult female Wistar rats weighing (150-200 g); they were obtained from faculty of pharmacy at King Abdulaziz University. The animals were housed in cages and received normal rat chow and tap water in a constant environment (room temperature $28 \pm 2{ }^{\circ} \mathrm{C}$, room humidity 60 $\pm 5 \%$ ) in a $12 \mathrm{~h}$ light and $12 \mathrm{~h}$ dark cycle. Rats were kept under supervision for two weeks before the experiments started and during all stages of the whole experiment. Animal's procedures were performed in accordance with the Ethics Committee of the King Fahad Medical Research Center and in accordance with the recommendations for the proper care and use of laboratory animals.

\subsection{Methods}

\subsubsection{Preparation of basil extracts}

The water extracts of raw or irradiated dried basil leaves were prepared according to the method described by Ghazwani, Osman and Balamash (2020).

The total antioxidant capacity was measured in basil extracts using the Total Capacity Assay kit with CAT\# STA-360.

\subsubsection{Experimental Design}


In the experiment, 48 rats were divided into six groups each of 8 rats as follows:

Group 1: normal control rats were given only distilled water.

Group 2: rats received $400 \mathrm{mg} / \mathrm{kg}$ of aqueous extract of raw basil (Ezeani et al., 2017) .

Group 3: rats received $400 \mathrm{mg} / \mathrm{kg}$ of aqueous extract of irradiated basil (Ezeani et al., 2017).

Group 4: rats received $10 \mathrm{mg} / \mathrm{kg}$ of sodium arsenate solution (Firdaus et al., 2018).

Group 5: rats received $10 \mathrm{mg} / \mathrm{kg}$ of sodium arsenate solution and $400 \mathrm{mg} / \mathrm{kg}$ of aqueous extract of basil.

Group 6: rats received $10 \mathrm{mg} / \mathrm{kg}$ of sodium arsenate solution and $400 \mathrm{mg} / \mathrm{kg}$ of aqueous extract of irradiated basil.

All doses were given through an oral gastric tube daily for five weeks.

At the end of the experiment, rats fasted overnight for scarification. Blood samples were withdrawn by a heparinized capillary tube from the retro-orbital plexus of each rat under anesthesia with diethyl ether, it is put into two tubes, one is ethylenediamine tetra-acetic acid (EDTA) tube and the other is a serumseparating tube. The EDTA tube immediately turned to lab analysis while serum-separating tube centrifuged at $3000 \mathrm{rpm}$ for $15 \mathrm{~min}$ to separate serum and then stored at $-40^{\circ} \mathrm{C}$ until the biochemical analysis is done. Directly after preparing the blood sample, rats sacrificed and the brain was kept in ice for homogenate preparation.

\subsection{Biochemical analysis}

The biochemical analysis for complete blood count (CBC) were done in Kingdoms Labs. The blood serum IgG, IgM and IgA, TNFa, IL-6 and CRP were identified using the kits with CAT\# ab189578, ab157735, ab157738, ab46070, ab119548, and ab108827, respectively. For tissue analysis, the brain was homogenized and estimated each of SOD, GSH, CAT and MDA according to the kits with CAT\# ab65354, ab138881, ab83464, and ab118970, respectively, while the protein concentration estimated in the brain was used Kits with CAT\# 23225.

\subsection{Statistical analysis}

The data of each group were analyzed using MegaStat 9.4 (add-in for Excel). The data were expressed as arithmetic mean and standard deviation of the mean (SD). Differences between groups were analyzed for parametric parameters using one-way variance analysis (ANOVA), the least significant difference equation (LSD). A $P$ value below or equal to 0.05 was considered significant.

\section{Results}

\subsection{Antioxidant in irradiated plant leaves}


The effect of irradiation on antioxidants is showed in Fig. 1. Where leaves treated with gamma irradiation (10 kGy) showed a change, a $10.3 \%$ increase in the content of total antioxidants compared to raw leaves not treated with radiation.

\subsection{Complete blood count (CBC)}

The effects of aqueous extracts of raw basil or irradiated basil for 5 weeks on the levels of hemoglobin $(H B)$, red blood cells $(R B C)$, hematocrit $(H C T)$, platelets (PLT), White blood cells (WBC), WBC differential and reticulocyte count in rats exposed to arsenic are present in Tables 1 and 2.

No effect of raw or irradiated basil administration in normal animals on all previous parameters was noted. Rats, which were exposed to arsenic showed a significant decrease in levels of HB, RBC, PLT, neutrophils (NEU), and lymphocytes (LYM) compared to the control group. While there was a marked increase in the levels of HCT, WBC, monocytes (MON) and reticulocyte count compared to the control group. Administration of raw and irradiated basil along with arsenic significantly reduced arsenic toxicity effect by the improvement levels of these parameters.

Table 1

Effect of basil extracts on hematological parameters of rats exposed to arsenic

\begin{tabular}{|lllll|}
\hline & HB & RBC & HCT & PLT \\
& $(\mathbf{g} / \mathbf{d l})$ & $\left(10^{\wedge} \mathbf{6} / \mathbf{m L}\right)$ & $(\%)$ & $\left(10^{\wedge} 3 / \mathbf{m L}\right)$ \\
\hline C & $12.661 \pm 1.258$ & $4.450 \pm 0.575$ & $29.635 \pm 1.870$ & $263.13 \pm 52.58$ \\
B & $12.725 \pm 0.902$ & $4.570 \pm 0.491$ & $29.286 \pm 0.516$ & $274.50 \pm 19.17$ \\
& bbb & bbb & bbb & bbb \\
\hline IB & $12.810 \pm 0.756$ & $4.568 \pm 0.487$ & $29.518 \pm 0.908$ & $277.25 \pm 13.63$ \\
& bbb & bbb & bbb & bbb \\
\hline A & $8.748 \pm 0.590$ & $3.100 \pm 0.524$ & $39.058 \pm 0.655$ & $143.25 \pm 7.96$ \\
& aaa & aaa & aaa & aaa \\
\hline B + A & $10.918 \pm 0.713$ & $4.066 \pm 0.463$ & $30.978 \pm 1.748$ & $188.38 \pm 10.89$ \\
& aaa & bbb & bbb & aaa \\
& bbb & & & bb \\
\hline IB + A & $11.249 \pm 0.290$ & $4.151 \pm 0.164$ & $32.330 \pm 1.863$ & $177.88 \pm 10.47$ \\
& aa & bbb & aaa & aaa \\
& bbb & & bbb & bb \\
\hline
\end{tabular}

Values are the mean of 8 observation $\pm S D$. 
Significant different from $C$ value at $P<0.05^{a}, 0.01^{\text {aa }}, 0.001^{\text {aaa }}$

Significant different from $A$ at value at $P<0.05^{b}, 0.01^{b b}, 0.001^{b b b}$

Table 2

Effect of basil extracts on hematological parameters of rats exposed to arsenic

\begin{tabular}{|llllll|}
\hline & WBC & \multicolumn{2}{l}{ WBC differential } & Reticulocyte Count \\
\cline { 3 - 5 } & $\left(10^{\wedge} \mathbf{3} / \mathrm{mL}\right)$ & NEU (\%) & LYM (\%) & MON (\%) & (\%) \\
\hline C & $5.661 \pm 0.508$ & $62.403 \pm 1.869$ & $28.16 \pm 2.658$ & $4.113 \pm 0.631$ & $1.413 \pm 0.416$ \\
B & $5.255 \pm 0.532$ & $63.388 \pm 1.886$ & $27.61 \pm 4.022$ & $4.250 \pm 0.460$ & $1.100 \pm 0.185$ \\
& bbb & bbb & bb & bbb & bbb \\
\hline IB & $5.134 \pm 0.604$ & $64.538 \pm 1.577$ & $29.46 \pm 4.530$ & $4.064 \pm 0.261$ & $1.263 \pm 0.424$ \\
& bbb & bbb & bbb & bbb & bbb \\
\hline A & $9.761 \pm 0.893$ & $38.051 \pm 2.361$ & $20.00 \pm 2.624$ & $7.150 \pm 0.493$ & $2.350 \pm 0.540$ \\
& aaa & aaa & aaa & aaa & aaa \\
\hline B + A & $6.160 \pm 0.825$ & $54.175 \pm 5.389$ & $24.95 \pm 5.687$ & $5.163 \pm 0.460$ & $1.011 \pm 0.110$ \\
& bbb & aaa & b & aaa & bbb \\
& & bbb & & bbb & \\
\hline IB + A & $5.978 \pm 0.610$ & $51.850 \pm 5.011$ & $25.73 \pm 5.035$ & $5.113 \pm 0.500$ & $1.163 \pm 0.518$ \\
& bbb & aaa & b & aaa & bbb \\
& & bbb & & bbb & \\
\hline
\end{tabular}

Values are the mean of 8 observation $\pm S D$.

Significant different from $C$ value at $P<0.05^{a}, 0.01^{a a}, 0.001^{\text {aaa }}$

Significant different from $A$ at value at $P<0.05^{b}, 0.07^{b b}, 0.007^{b b b}$

\subsection{Antibodies}

The extract of each raw and irradiated basil had distinct effects on antibodies in rats exposed to arsenic that are showed in Table 3.

The treatment with raw or irradiated basil to normal animals not producing an effect on levels of serum $\lg G$, IgM and IgA. The arsenic group showed a significant decrease in IgG, IgM and IgA levels compared to the control group. The treatment with basil extract as raw or irradiated along with arsenic dose was 
showed a significant increase in those antibodies' levels, compared with the group of rats given only arsenic.

\section{Table 3}

Effect of basil extracts on immunoglobulins of rats exposed to arsenic

\begin{tabular}{|llll|}
\hline & $\begin{array}{l}\text { IgG } \\
(\mu \mathrm{g} / \mathrm{ml})\end{array}$ & $\begin{array}{l}\text { lgM } \\
(\mu \mathrm{g} / \mathrm{ml})\end{array}$ & $\begin{array}{l}\text { lgA } \\
(\mu \mathrm{g} / \mathrm{ml})\end{array}$ \\
\hline C & $517.16 \pm 35.137$ & $0.628 \pm 0.084$ & $90.180 \pm 6.688$ \\
\hline B & $522.490 \pm 41.527$ & $0.640 \pm 0.053$ & $93.236 \pm 7.697$ \\
& bbb & bbb & bbb \\
\hline IB & $514.663 \pm 32.665$ & $0.655 \pm 0.064$ & $94.614 \pm 5.087$ \\
& bbb & bbb & bbb \\
\hline A & $202.500 \pm 40.818$ & $0.226 \pm 0.024$ & $45.779 \pm 5.816$ \\
& aaa & aaa & aaa \\
\hline B + A & $298.911 \pm 32.731$ & $0.389 \pm 0.015$ & $72.754 \pm 4.942$ \\
& aaa & aaa & aaa \\
& bbb & bbb & bbb \\
\hline IB + A & $287.915 \pm 35.128$ & $0.408 \pm 0.021$ & $76.745 \pm 4.229$ \\
& aaa & aaa & aaa \\
& bbb & bbb & bbb \\
\hline Values are the mean of 8 observation $\pm S D$. & \\
\hline
\end{tabular}

Significant different from $C$ value at $P<0.05^{a}, 0.01^{\text {aa }}, 0.001^{\text {aaa }}$

Significant different from $A$ at value at $P<0.05^{b}, 0.07^{b b}, 0.007^{b b b}$

\subsection{Inflammatory markers}

The level of markers of inflammation in rats exposed to arsenic which received raw or irradiated basil as a treatment showed in Table 4.

In normal animals, the administration of raw or irradiated basil has not had an effect on the levels of serum TNF, IL-6 and CPR. The rats exposed to arsenic showed a significant increase in levels of TNF, IL-6, and CPR as compared to the control group. While giving raw or irradiated basil extract was noted significantly reduced in these inflammatory markers induced by arsenic. 
Table 4

Effect of basil extracts on the inflammation markers of rats exposed to arsenic

\begin{tabular}{|llll|}
\hline & $\begin{array}{l}\text { TNFa } \\
(\mathbf{p g} / \mathrm{ml})\end{array}$ & $\begin{array}{l}\text { IL-6 } \\
(\mathrm{pg} / \mathrm{ml})\end{array}$ & $\begin{array}{l}\text { CRP } \\
(\mathrm{ng} / \mathrm{ml})\end{array}$ \\
\hline C & $17.829 \pm 1.221$ & $21.048 \pm 2.134$ & $0.134 \pm 0.039$ \\
\hline B & $16.144 \pm 1.428$ & $20.753 \pm 1.962$ & $0.134 \pm 0.034$ \\
& bbb & bbb & bbb \\
\hline IB & $16.123 \pm 1.216$ & $20.456 \pm 2.940$ & $0.140 \pm 0.018$ \\
& bbb & bbb & bbb \\
\hline A & $40.043 \pm 2.453$ & $35.334 \pm 3.973$ & $0.990 \pm 0.076$ \\
& aaa & aaa & aaa \\
\hline B + A & $27.656 \pm 2.173$ & $27.413 \pm 3.842$ & $0.660 \pm 0.093$ \\
& aaa & aaa & aaa \\
& bbb & bbb & bbb \\
\hline IB + A & $28.935 \pm 2.634$ & $26.876 \pm 1.563$ & $0.490 \pm 0.033$ \\
& aaa & aaa & aaa \\
& bbb & bbb & bbb \\
\hline Values are the mean of 8 observation $\pm S D$. & \\
\hline
\end{tabular}

Significant different from $C$ value at $P<0.05^{a}, 0.01^{a a}, 0.001^{\text {aaa }}$

Significant different from $A$ at value at $P<0.05^{b}, 0.01^{b b}, 0.001^{b b b}$

\subsection{Antioxidants and oxidative damage}

The results of determining the content of SOD, GSH, CAT and MDA in rats given arsenic along with raw basil or irradiated basil were shown in Table 5 .

The normal rats treated with irradiated basil showed an increase in the level of SOD than rats treated with raw basil. The level of GSH was showed an increase in normal rats of both of raw basil group and irradiated basil group as compared to the control group. Arsenic-exposed rats showed a significant increase in MDA levels accompanied by a significant decrease in SOD, GSH and CAT compared to a control group. The management of raw or irradiated basil along with arsenic alleviated the effects of arsenic and resulted in a significantly decreased MDA with significantly increased SOD, GSH, CAT. 
Table 5

Effect of basil extracts on the antioxidants and oxidative damage in the brain of rats exposed to arsenic

\begin{tabular}{|c|c|c|c|c|}
\hline & $\begin{array}{l}\text { SOD } \\
\text { (Inhibition rate \% / mg of } \\
\text { protein) }\end{array}$ & $\begin{array}{l}\text { GSH } \\
(\mu \mathrm{M} / \text { gram } \\
\text { tissue) }\end{array}$ & $\begin{array}{l}\text { CAT } \\
\text { ( } \mu \mathrm{M} / \mathrm{mg} \text { of } \\
\text { protein) }\end{array}$ & $\begin{array}{l}\text { MDA } \\
\text { ( } \mu \mathrm{M} / \mathrm{mg} \text { of } \\
\text { protein) }\end{array}$ \\
\hline C & $105.406 \pm 7.342$ & $90.743 \pm 7.044$ & $0.020 \pm 0.003$ & $2.496 \pm 0.451$ \\
\hline B & $\begin{array}{l}107.548 \pm 9.384 \\
\text { bbb }\end{array}$ & $\begin{array}{l}96.709 \pm 3.420 \\
\text { a } \\
\text { bbb }\end{array}$ & $\begin{array}{l}0.019 \pm 0.004 \\
b b b\end{array}$ & $\begin{array}{l}2.400 \pm 0.422 \\
b b b\end{array}$ \\
\hline IB & $\begin{array}{l}114.655 \pm 8.165 \\
\mathrm{a} \\
\mathrm{bbb}\end{array}$ & $\begin{array}{l}95.425 \pm 4.426 \\
\text { a } \\
\text { bbb }\end{array}$ & $\begin{array}{l}0.021 \pm 0.004 \\
b b b\end{array}$ & $\begin{array}{l}2.441 \pm 0.433 \\
\text { bbb }\end{array}$ \\
\hline A & $\begin{array}{l}77.977 \pm 10.370 \\
\text { aaa }\end{array}$ & $\begin{array}{l}60.248 \pm 2.657 \\
\text { aaa }\end{array}$ & $\begin{array}{l}0.009 \pm 0.000 \\
\text { aaa }\end{array}$ & $\begin{array}{l}6.005 \pm 0.126 \\
\text { aaa }\end{array}$ \\
\hline$B+A$ & $\begin{array}{l}82.049 \pm 8.953 \\
\text { aaa } \\
\text { bbb }\end{array}$ & $\begin{array}{l}84.259 \pm 4.487 \\
\text { aa } \\
\text { bbb }\end{array}$ & $\begin{array}{l}0.012 \pm 0.001 \\
\text { aaa }\end{array}$ & $\begin{array}{l}3.479 \pm 0.610 \\
\text { aaa } \\
\text { bbb }\end{array}$ \\
\hline $\begin{array}{l}\mathrm{IB}+ \\
\mathrm{A}\end{array}$ & $\begin{array}{l}89.249 \pm 9.381 \\
\text { aaa } \\
\text { bbb }\end{array}$ & $\begin{array}{l}82.533 \pm 3.153 \\
\text { aa } \\
\text { bbb }\end{array}$ & $\begin{array}{l}0.014 \pm 0.003 \\
\text { aa } \\
\text { bb }\end{array}$ & $\begin{array}{l}3.165 \pm 0.484 \\
\text { aa } \\
\text { bbb }\end{array}$ \\
\hline
\end{tabular}

Significant different from $C$ value at $P<0.05^{a}, 0.01^{\text {aa }}, 0.001^{\text {aaa }}$

Significant different from $A$ at value at $P<0.05^{b}, 0.07^{b b}, 0.007^{b b b}$

\section{Discussion}

\subsection{Antioxidant in irradiated plant leaves}

The irradiation treatment can increase the content of some phytochemicals and the plant's antioxidant activity, thereby increased biological value (Zevallos-Concha et al., 2016; Pereira et al., 2018). The results indicated that the extract of irradiated basil showed a highly significant increase in total antioxidants as a comparison to raw basil. Similar observations were reported in previous studies on basil and some other plants (Khawory et al., 2020; Osman, Ghazwani and Balamash, 2020; Rady et al., 2020). 
Basil contains phenolic compounds and flavonoids (Bahcesular et al., 2020), that are considered as natural antioxidants. These biomolecules exhibit their activity through various mechanisms, including inhibiting enzymes that inducing free radical produce, increasing endogenous antioxidants, removing free radicals, and inducing the expression of the numerous genes responsible for enzyme synthesis that inhibit oxidative stress (Primiano, Sutter and Kensler, 1997). Ghazwani, Osman and Balamash (2020) reported that the Fourier-transform infrared (FTIR) analysis indicated to increase the content of phenolic acids and flavonoids in basil leaves after treated with $10 \mathrm{kGy}$ of gamma-ray. Moreover, Maraei, Khaled and Elsawy (2017) reported that the gamma irradiation-induced the biosynthesis of certain phenolic compounds. Also, it seems that gamma irradiation with $10 \mathrm{kGy}$ might stimulate some chemical reactions in basil, which perhaps increase in phenolic content by the breakdown of covalence bonds among phenolic components and, free phenolic components with low molecular weight are increasing (Jamshidi, Barzegar and Sahari, 2014).

\subsection{Complete blood count (CBC)}

A complete blood count test is a blood test used to assess general health and detect a range of disorders in hematological parameters. A complete blood count test measures many blood components and features, including red blood cells that carry oxygen, white blood cells that fight infection, hemoglobin that oxygen-carrying protein in red blood cells, hematocrit that indicate to the ratio of red blood cells to the liquid or plasma component of the blood and platelets that help blood clot, and that any change whether an abnormal rise or decrease in the census, indicate the incidence of diseases or disorders requiring medical procedures (Clinic, 2018).

In our study, it has been observed that the levels of HB, RBC, PLT, NEU, and LYM are decreased significantly with a marked increase in the HCT, WBC, MON and reticulocyte count in rats exposed to arsenic compared to the control group. The results are consistent with some studies (Kajiguchi et al., 2005; Bhattacharya and Haldar, 2012; Sumedha and Miltonprabu, 2013; Lemaire et al., 2015; Ghosh et al., 2017; Su et al., 2018). This effect of Arsenic exposure on the hematopoietic system may be attributed to the mechanisms of arsenic toxicity which may induce hemolysis and erythrophagocytosis through increased oxidation of sulfhydryl groups in hemoglobin and decreased oxygen intake by cells as a result of decreased intracellular glutathione, which decreases the lifespan of erythrocytes (Abdul et al., 2015). Moreover, arsenic exposure can also cause a range of changes, such as increasing ceramide formation, membrane disintegration, cytosolic calcium levels, besides decreasing in adenosine triphosphate (ATP) levels, cell membrane integrity affecting erythrocyte lifespan (Abdul et al., 2015).

Regarded the change in platelet count, this confirmed that arsenic inhibited platelet differentiation within the hematopoietic system of bone marrow, leading to reduced platelet production (Wu et al., 2014).

The white blood cell level was decreased in arsenic feed groups. It might be due to the impact of arsenic which induced apoptotic effect on plasma cells as noted by Rousselot et al. (2004). WBC may generally be divided into five classes, based on their function, morphology and origin: LYM, MON and NEU (Villa et 
al., 2003). The changes in the LYM and NEU populations present in this study may be due to arsenic caused immune inhibition in rats (Taheri et al., 2016).

Our findings demonstrated that extracts of basil caused improved the disorders that occur in CBC. This is in agreement with the results of previous researches (Ofem, Ani and Eno, 2012; Zangeneh et al., 2019). This effect may due to basil which contains a proportion of iron (Nworgu, Yekini and Oduola, 2013), that contributes to improving the level of HB in the blood and has the ability to stimulate production and increase of RBC to treat deficiency caused by arsenic. Furthermore, in normal, the lack of oxygen in the local tissue appears to lead to the production of glycoprotein known as erythropoietin, which induces increased erythrocyte output (Bowman and Rand, 1980). Basil leaves extract is very likely to contain erythropoietin-like agents that are responsible for increased erythrocyte production (Ofem, Ani and Eno, 2012). Saha et al. (2012) reported that secondary metabolites of basil, consisting of important elements include essential oil geraniol, a monoterpene and citral, play a role as the modulator in hematological abnormalities (Ofem, Ani and Eno, 2012). Moreover, in results about the increased lymphocyte count after basil administration, it has been reported that Ocimum basilicum modulates the cell-mediated as well as a humoral immune response that could be due to the presence of flavonoids and terpenoids (Mediratta, Sharma and Singh, 2002).

\subsection{Antibodies}

Antibodies also are known as immunoglobulins, are substances made by the body's immune system in response to foreign substances. Antibodies bind to these foreign substances and they can be killed by the immune system. IgG, IgM and IgA from the major types of antibodies. If reduced levels of antibodies produced by the immune system, it leads to more likely to develop repeated infections (Staff, 2019).

The results of our study showed that in the arsenic group of rats $(10 \mathrm{mg} / \mathrm{kg} \mathrm{BW})$ a highly significant reduction was observed in IgG, IgA and IgM levels compared to the control group. The results are consistent with some studies (Institoris et al., 2001; Sankar et al., 2013). The effect on immunoglobulin levels associated with arsenic exposure can attribute to the arsenic disrupts glucocorticoid regulation, responsible for immune function (Kaltreider et al., 2001). Furthermore, the apoptosis caused by arsenic may result in decreased immune responses (Harrison and McCoy, 2001).

The administration of water extract from raw or irradiated basil extract demonstrated a protective effect against arsenic toxicity in rats, by increasing antibodies that decreased as a result of arsenic poisoning. These results are in line with the findings of Mohammed, Kadhim and Taher (2017) and Jahejo et al. (2019). Jeba, Vaidyanathan and Rameshkumar (2011) showed that aqueous extract of basil stimulated the antibody production in rats. The flavonoids present in the basil leaves are mainly responsible for the immunomodulatory effect (Ravindran, 2017).

\subsection{Inflammatory markers}

Inflammation is a biological response of the immune system which can be induced by damaged cells, toxic compounds or pathogens (Medzhitov, 2010). It is part of the body's defense mechanism. one of the 
major aims of inflammation is to bring immune cells to the area of concern as well as to inactivate or destroy any injurious stimuli and to also begin the repair (Ferrero-Miliani et al., 2007; Medzhitov, 2010). The inflammation response is caused by specific immune factors released from the damaged cells. Where, the damaged cells release cytokines, including interleukins, such as IL-6, IL-8, and tumor necrosis factor- $a$, that are responsible for communication between white blood cells. Interleukins also stimulate the production and release of CRP from the liver; an important component of the innate immune system (Sinclair, Wang and Tetrick, 2012).

Usually, molecular and cellular activities and interactions efficiently alleviate inevitable infection or damage, during acute inflammatory responses. This effect helps restore homeostasis in the tissue and overcome the acute inflammation. Uncontrolled acute inflammation can become chronic, however, and can lead to a number of chronic inflammatory diseases (Zhou, Hong and Huang, 2016). The elevated levels of inflammatory markers are expected to be associated with toxic metals exposure.

Results of this study showed that serum IL-6, TNF- $a$ and CRP level in rats exposed to arsenic was highly significantly elevated. Our findings agree with the results of the previous study on the association between arsenic and ability to cause chronic inflammation by demonstrating the increased proinflammatory mediators like TNF-a, IL-6 and CRP in the arsenic exposed group in comparison to the control group (Prasad and Sinha, 2017). Inflammation considered to be one of the main arsenic toxicity mechanisms that can be correlated with increasing cellular damages, oxidative stress and lipid peroxidation (Bhadauria and Flora, 2007).

In this work also, it was demonstrated that oral treatment with basil extracts diminished inflammations in rats exposed to arsenic. These results in agreement with Aye et al. (2019) and Takeuchi et al. (2020) who found that basil has anti-inflammatory effects. Rodrigues et al. (2016) reported that the basil essential oil was effective in reducing inflammations (acute or chronic) by induced inhibiting of the inflammatory mediator receptors and the migration of cells to stimulus locations. This may be attributed to the contains of basil of rosmarinic acid (Kwon et al., 2019), where this compound has been related to antiinflammatory activities (Luo et al., 2020).

\subsection{Antioxidants and oxidative damage}

Antioxidants are considered the enzymes of the body's protection, are able to stabilize free radicals before attacking components of the cell. They work to diminishing free radicals through reducing their energy or donate electrons to them, thus making it stable (Krishnamurthy and Wadhwani, 2012). While, "oxidative stress, defined as a disturbance in the balance between the production of reactive oxygen species (free radicals) and antioxidant defenses" (Betteridge, 2000).

In the present study, observed a very highly significant decrease in GSH, SOD and CAT accompanied by increased MDA of the rat's brain in the arsenic group as compared to the normal control group. This result is similar to the study of Sun et al. (2018) that reported that arsenic caused significantly decreased GSH, SOD and CAT with increased MDA content in the brain tissues of chickens. This may be attributed to the 
toxic effect of arsenic that may induce oxidative stress by interacting with antioxidants, resulting in the accumulation of free radicals in cells (Bonetto, Villaamil Lepori and Puntarulo, 2014).

In contrast, basil giving a positive effect on the brain by improving the levels of antioxidant antioxidants, and fat oxidation (MDA). These results were in line with recent studies showed that the water extract of gamma-irradiated basil contributes to improving the oxidative stress induced by arsenic exposure in rats (Ghazwani, Osman and Balamash, 2020; Osman, Ghazwani and Balamash, 2020). Also agree with the results of Khodabakhshi et al. (2017), who proved that the increased level of MDA in the mice brain tissue following seizures was prevented by basil extract. Moreover, Khaki (2016) demonstrated that the basil extract protects brain cells from the harmful effects by regulating the antioxidant enzymes in the serum. This saves the neurons from irreversible cell injury. The antioxidant effect is due primarily to phenolic elements, such as, phenolic acids and flavonoids, which have redox properties and ability to neutralize free radicals (Shahidi, Janitha and Wanasundara, 1992).

\section{Conclusion}

In this study, we demonstrated that gamma radiations have the ability to increases antioxidants contents in basil leaves. Moreover, the water extracts obtained from Ocimum basilicum can be successful in diminished arsenic toxic effect through the improvement of the homeostasis of CBC and immunoglobins level, reduced inflammatory markers and, enhancement ability of antioxidants to be overcome oxidative stress in the brain.

\section{Declarations}

\section{Ethical approval and consent to participate:}

This article prepared by Mrs. Batoul Sami Amjad with the participation of a number of authors who contributed to the audit, review and supervision.

\section{Consent for publication:}

I am Mrs. Batoul Sami Amjad, the author of this article; I want to publish it in your journal. In addition, all the authors who participate with me agree to publish and there is no objection from any of them.

\section{Availability of data and materials}

The full research facility contains all the data and materials used in the study

\section{Thanks and appreciation}

Thanks to all of the participants and moderators for completing this research

\section{Competing interests:}


The authors reported no potential conflict of interest

\section{Funding:}

Not applicable

\section{Authors' contributions}

Dr. Nadia N. Othman contributed to the supervision, Dr. Khadija Balamash contributed to the review, and Aisha Ghazwani contributed to the revision and correction

\section{Acknowledgment}

In the Name of Allah, the Most Merciful, the Most Compassionate all praise be to Allah, the Lord of the worlds; and prayers and peace be upon Mohamed His servant and messenger.

Firstly, I would like to express my gratitude thanks to my supervisor Dr. Nadia Nour for her great support in my Master thesis and its related research, for her patience, motivation, and immense knowledge. Her guidance helped me in all the time of research and writing of this thesis. I could not have imagined having a better supervisor for my master study. Besides, my supervisor, I would like to thank Dr. Khadiaja Balaamesh, for her insightful comments, encouragement and for her support during all stages. I owe a deep debt of gratitude to our university for giving us an opportunity to complete this work.

Nobody has been more important to me in the pursuit of this project than the members of my family. I would like to thank my parents, whose love and guidance are with me in whatever I pursue. They are the ultimate role models. Most importantly, I wish to thank my loving and supportive husband, Ahmad, and my three wonderful children, Maria, Aseel and Raffa, who provide unending inspiration. Finally, I would like to thank my great friend Ayshaa Ghazwani for her help and support at all times.

\section{Authors' information (optional)}

\section{Dr. Nadia N. Osman}

- Department of Biochemistry, King Abdulaziz University, Jeddah, Saudi Arabia

- Department of Food Irradiation Research, National Centre for Radiation Research and Technology, Cairo, Egypt

- E-mail:dr_nadia_nour@yahoo.com

\section{Batoul S Amjad}

- Department of Biochemistry, King Abdulaziz University, Jeddah, Saudi Arabia

- E-mail: batoulamjad@gmail.com

\section{Aishah H. Ghazwani}


- Department of Biochemistry, King Abdulaziz University, Jeddah, Saudi Arabia

- E-mail: aishahghazwani@gmail.com

Dr. Khadijah S. Balamash

- Department of Biochemistry, King Abdulaziz University, Jeddah, Saudi Arabia

- E-mail: kbalamash@kau.edu.sa

\section{Abbreviations}




\begin{tabular}{|c|c|}
\hline AAP & 4-aminophenzone \\
\hline ADP-ribose & Adenosine diphosphate ribose \\
\hline ALP & Alkaline phosphatase \\
\hline ALT & Alanine Aminotransferase \\
\hline AM & Alternative Medicine \\
\hline AOM & Azoxymethane \\
\hline AS & Arsenic \\
\hline AST & Aspartate Aminotransferase \\
\hline B Cells & B lymphocytes (a type of white blood cell of the lymphocyte subtype) \\
\hline Basil & Ocimum basilicum \\
\hline BCP & Beta-caryophyllene \\
\hline BHT & Butylated hydroxytoluene \\
\hline CAT & Catalase \\
\hline $\mathrm{CCl} 4$ & carbon tetrachloride \\
\hline CRP & C-Reactive Protein \\
\hline $\mathrm{C}_{\mathrm{S}}$ & Cesium-137 \\
\hline DHBS & Dichloro -2-hydroxybenzene sulfonic acid \\
\hline${ }^{60} \mathrm{CO}$ & Cobalt-60 \\
\hline DM & Diabetes Mellitus \\
\hline DNA & Deoxyribonucleic acid \\
\hline ELISA & Enzyme-Linked Immunosorbent Assay \\
\hline EMG & Electromyography \\
\hline g & gram \\
\hline GC & Gas Chromatography \\
\hline GC/MS & Gas Chromatography/Mass Spectrometry \\
\hline GPx & Glutathione Peroxidase \\
\hline GRD & Glutathione Reductase \\
\hline GSH & Reduced Glutathione \\
\hline GSR & Glutathione Reductase \\
\hline
\end{tabular}




\begin{tabular}{|c|c|}
\hline GSSG & Glutathione disulfide \\
\hline GST & Glutathione S-Transferase \\
\hline $\mathrm{H}_{2} \mathrm{O}$ & Water \\
\hline $\mathrm{H}_{2} \mathrm{O}_{2}$ & Hydrogen Peroxide \\
\hline HAase & Hyaluronidase \\
\hline $\mathrm{HB}$ & Hemoglobin \\
\hline HBPP & Human Brain Proteome Project \\
\hline HCT & Haematocrit \\
\hline HRP & Enzyme Horseradish Peroxidase \\
\hline $\lg \mathrm{A}$ & Immunoglobulin G (Immunoglobulin A is an antibody) \\
\hline $\lg G$ & Immunoglobulin G, is a type of antibody \\
\hline $\lg M$ & immunoglobulin M Antibody \\
\hline $\mathrm{IL}-1$ & The Interleukin-1 \\
\hline IL-6 & Interleukin-6 \\
\hline $\mathrm{KCl}$ & Potassium chloride \\
\hline $\mathrm{Kg}$ & Kilograms \\
\hline L & liter \\
\hline LOP & Lipid peroxidation \\
\hline LPO & Lipid Peroxidation \\
\hline LSD & Least Significant Difference \\
\hline MAPKs & Mitogen Activated Protein Kinases \\
\hline MDA & Malondialdehyde \\
\hline $\mathrm{mM}$ & Macromolecule \\
\hline $\mathrm{mmol} / \mathrm{L}$ & Millimoles per Liter \\
\hline mRNA & Messenger Ribonucleic acid \\
\hline MS & Mass spectrometry \\
\hline $\mathrm{Na}_{3} \mathrm{AsO}_{4}$ & Sodium Arsenate solution \\
\hline NADPH & Nicotinamide Adenine Dinucleotide Phosphate \\
\hline \multirow[t]{2}{*}{$\mathrm{NaHCO} 3$} & Sodium bicarbonate \\
\hline & Page 18/27 \\
\hline
\end{tabular}




\begin{tabular}{|c|c|}
\hline NBT & Nitroblue tetrazolium \\
\hline NCRRT & National Centre for Radiation Research and Technology \\
\hline $\mathrm{nm}$ & nanometer \\
\hline $\mathrm{nmol} / \mathrm{mg}$ & nanomole per milligram \\
\hline NO & Nitric Oxide \\
\hline NO. & Number \\
\hline NOS & Nitric Oxide Synthase \\
\hline $0^{-}$ & Oxygen Free Radical \\
\hline $\mathrm{O}_{2}$ & Oxygen \\
\hline $\mathrm{O}_{2}^{-}$ & Superoxide \\
\hline OBO & Ocimum basilicum oil \\
\hline $\mathrm{OC}$ & Oral Contraceptive \\
\hline${ }^{\circ} \mathrm{C}$ & Celsius \\
\hline OGTT & Oral Glucose Tolerance Test \\
\hline $\mathrm{OH}^{-}$ & Hydroxyl \\
\hline OS & Oxidative Stress \\
\hline PARP & Polymerase \\
\hline PBS & Phosphate Buffered Saline \\
\hline $\mathrm{pg} / \mathrm{ml}$ & Picogram per milliliter \\
\hline $\mathrm{pH}$ & a scale of acidity from 0 to 14 \\
\hline PLT & Platelets \\
\hline PMS & Phenazine methosulphate \\
\hline PMSF & Phenylmethylsulfonyl fluoride \\
\hline $\mathrm{RBC}$ & Red Blood Cells \\
\hline $\mathrm{RCOOH}$ & Carboxylic Acid \\
\hline RNA & Ribonucleic acid \\
\hline RNS & Reactive Nitrogen Species \\
\hline ROS & receptive oxygen species \\
\hline
\end{tabular}




\begin{tabular}{ll} 
ROS & Reactive Oxygen Species \\
\hline SD & Sexual dysfunction \\
\hline SOD & Superoxide Dismutase \\
\hline STZ & Streptozotocin \\
\hline STZ & Streptozotocin \\
\hline T Cells & T lymphocyte, is a type of lymphocyte (a subtype of white blood cell) \\
\hline TAC & total antioxidant capacity \\
\hline TBARS & Thiobarbituric Acid Reactive Substances \\
\hline TCA & Trichloroacetic \\
\hline TNFa & Tumor necrosis factor alpha \\
\hline Tris/HCl & Tris Hydrochloride \\
\hline Triton X-100 & A Commonly Used Detergent In Laboratories \\
\hline USEPA & U.S. Environmental Protection Agency \\
\hline WBC & White Blood Cell \\
\hline WHO & World Health Organization \\
\hline$\beta$ & Beta \\
\hline$\beta-M E$ & $\beta-$ Methylphenethylamine \\
\hline$\mu / d l$ & Milligram per deciliter \\
\hline$\mu g$ & Microgram \\
\hline$\mu L$ & microliter \\
\hline
\end{tabular}

\section{References}

1. Abdul KSM, Jayasinghe SS, Chandana EP, Jayasumana C, De Silva PMC (2015), Arsenic and human health effects: A review, Environmental toxicology and pharmacology, vol.40: 828-846

2. Alomar MY, Al-Attar AM (2019) Effect of Basil Leaves Extract on Liver Fibrosis Induced by Thioacetamide in Male Rats. International Journal of Pharmacology vol 15::478-485

3. Alothman M, Bhat R, Karim A (2009) Effects of radiation processing on phytochemicals and antioxidants in plant produce. Trends Food Sci Technol 20::201-212

4. ATSDR (2017) ATSDR's Substance Priority List. Agency for Toxic Substances and Disease Registry, Atlanta 
5. Aye A, Jeon Y-D, Lee J-H, Bang K-S, Jin J-S (2019), Anti-inflammatory activity of ethanol extract of leaf and leaf callus of basil (Ocimum basilicum L.) on RAW 264.7 macrophage cells, Oriental Pharmacy and Experimental Medicine, vol.19: 217-226

6. Bahcesular B, Yildirim ED, Karaçocuk M, Kulak M, Karaman S (2020), Seed priming with melatonin effects on growth, essential oil compounds and antioxidant activity of basil (Ocimum basilicum L.) under salinity stress, Industrial Crops and Products, vol.146: 112165

7. Bent S (2008) Herbal medicine in the United States: review of efficacy, safety, and regulation. J Gen Intern Med 23:854-859

8. Betteridge DJ (2000), What is oxidative stress?, Metabolism-Clinical and Experimental, vol.49: 3-8

9. Bhadauria S, Flora S (2007), Response of arsenic-induced oxidative stress, DNA damage, and metal imbalance to combined administration of DMSA and monoisoamyl-DMSA during chronic arsenic poisoning in rats, Cell biology and toxicology, vol.23: 91-104

10. Bhattacharya S, Haldar PK (2012), Ameliorative effect Trichosanthes dioica root against experimentally induced arsenic toxicity in male albino rats, Environmental toxicology and pharmacology, vol.33: 394-402

11. Bonetto JG, Lepori V, E. C. and Puntarulo S (2014) Update on the oxidative stress associated with arsenic exposure. Current Topics in Toxicology vol 10::37-47

12. Blackwell Scientific Publications

Textbook of pharmacology

Bowman WC, Rand MJ (1980), Textbook of pharmacology: Blackwell Scientific Publications

13. Byun M-W, Yook H-S, Kim K-S, Chung C-K (1999) Effects of gamma irradiation on physiological effectiveness of Korean medicinal herbs. Radiat Phys Chem 54::291-300

14. Chatterjee S, Kumar V, Khole S, Sanyal B, Murali T, Variyar PS (2016), Radiation processing: An effective quality control tool for hygienization and extending shelf life of a herbal formulation, Amritamehari churnam, Journal of Radiation Research and Applied Sciences, vol.9: 86-95

15. Chiocchetti GM, Vélez D, Devesa V (2018), Effect of subchronic exposure to inorganic arsenic on the structure and function of the intestinal epithelium, Toxicology letters, vol.286: 80-88

16. Clinic M (2018), Complete blood count (CBC), From: https://www.mayoclinic.org/testsprocedures/complete-blood-count/about/pac-20384919. Access date; Apr. 14, 2020, 2020

17. Duker A, Ndur S, EMJnr O, A. I. and Apedo G (2018), Drinking Arsenic Water May Contribute to Mycobac-terium ulcerans, Archives of Epidemiology, vol.2018: 7

18. Eardley S, Bishop FL, Prescott P, Cardini F, Brinkhaus B, Santos-Rey K, Vas J, von Ammon K, Hegyi G, Dragan S (2012), A systematic literature review of complementary and alternative medicine prevalence in EU, Complementary Medicine Research, vol.19: 18-28

19. Eftekhar N, Moghimi A, Roshan NM, Saadat S, Boskabady MH (2019) Immunomodulatory and antiinflammatory effects of hydro-ethanolic extract of Ocimum basilicum leaves and its effect on lung pathological changes in an ovalbumin-induced rat model of asthma. BMC Complementary Alternative Medicine 19:349 
20. Ezeani C, Ezenyi I, Okoye T, Okoli C (2017) Ocimum basilicum extract exhibits antidiabetic effects via inhibition of hepatic glucose mobilization and carbohydrate metabolizing enzymes. Journal of Intercultural Ethnopharmacology vol 6::22-28

21. Farkas J (2006) Irradiation for better foods. Trends Food Sci Technol 17:148-152

22. Ferrero-Miliani L, Nielsen O, Andersen P, Girardin S (2007), Chronic inflammation: importance of NOD2 and NALP3 in interleukin-1 $\beta$ generation, Clinical \& Experimental Immunology, vol.147: 227235

23. Firdaus F, Zafeer MF, Waseem M, Ullah R, Ahmad M, Afzal M (2018) Thymoquinone alleviates arsenic induced hippocampal toxicity and mitochondrial dysfunction by modulating mPTP in Wistar rats. Biomed Pharmacother 102::1152-1160

24. Flanagan SV, Johnston RB, Zheng Y (2012), Arsenic in tube well water in Bangladesh: health and economic impacts and implications for arsenic mitigation, Bulletin of the World Health Organization, vol.90: 839-846

25. a Technique for microbial Decontamination of medicinal Plants Irradiation Garg N, Gupta PC (2016), Irradiation: a Technique for microbial Decontamination of medicinal Plants: Springer

26. Ghazwani AH, Osman NN, Balamash KS (2020), Role of Gamma-irradiated Basil (Ocimum basilicum) in the Alleviation of Heart Toxicity Induced by Arsenic in Rats, International Journal of Pharmaceutical and Phytopharmacological "in press\&\#8221

27. Ghosh S, Mishra R, Biswas S, Bhadra RK, Mukhopadhyay PK (2017) a-Lipoic acid mitigates arsenicinduced hematological abnormalities in adult male rats. Iranian journal of medical sciences $42: 242-$ 250

28. Harrison MT, McCoy KL (2001), Immunosuppression by arsenic: a comparison of cathepsin L inhibition and apoptosis, International immunopharmacology, vol.1: 647-656

29. Huq SI, Joardar J, Parvin S, Correll R, Naidu R (2006) Arsenic contamination in food-chain: transfer of arsenic into food materials through groundwater irrigation. J Health Popul Nutr 24:305-316

30. Institoris L, Siroki O, Űndeger Ű, Basaran N, Desi I (2001), Immunotoxicological investigation of subacute combined exposure by permethrin and the heavy metals arsenic (III) and mercury (II) in rats, International immunopharmacology, vol.1: 925-933

31. Jahejo AR, Rajput N, Wen-xia T, Naeem M, Kalhoro DH, Kaka A, Niu S, Jia F-j (2019) Immunomodulatory and Growth Promoting Effects of Basil (Ocimum basilicum) and Ascorbic Acid in Heat Stressed Broiler Chickens. Pakistan Journal of Zoology vol 51::801-807

32. Jakovljević Z, Topuzović D, Bojović B, Stanković MS Characteristics of germination and biomass production of Ocimum basilicum L. cultured in vitro. The 21th Conference about Biotechnology with international participation, Čačak, Serbia, Conference Proceeding (2016) 663-666

33. Jamshidi M, Barzegar M, Sahari M (2014), Effect of gamma and microwave irradiation on antioxidant and antimicrobial activities of Cinnamomum zeylanicum and Echinacea purpurea, 
International Food Research Journal, vol.21

34. Jeba C, Vaidyanathan R, Rameshkumar G (2011) Immunomodulatory activity of aqueous extract of Ocimum sanctum in rat. International Journal on Pharmaceutical Biomedical Research 2::33-38

35. Kajiguchi T, Yamamoto K, Sawa M, Emi N, Naoe T (2005), Increased erythropoietin level and reticulocyte count during arsenic trioxide therapy, Leukemia, vol.19: 1-3

36. Kaltreider RC, Davis AM, Lariviere JP, Hamilton JW (2001), Arsenic alters the function of the glucocorticoid receptor as a transcription factor, Environmental health perspectives, vol.109: 245251

37. Khaki A (2016) Protective Effect of ocimum basilicum on brain cells exposed to oxidative damage by electromagnetic field in rat: ultrastructural study by transmission electron microscopy. Crescent Journal of Medical Biological Sciences 3::1-7

38. Khawory MH, Sain AA, Rosli MAA, Ishak MS, Noordin MI, Wahab HA (2020), Effects of gamma radiation treatment on three different medicinal plants: Microbial limit test, total phenolic content, in vitro cytotoxicity effect and antioxidant assay, Applied Radiation and Isotopes, vol.157: 109013

39. Khodabakhshi T, Beheshti F, Hosseini M, Mousavi SM, Rakhshandeh H, Sadeghnia HR, Aghaei A (2017), Effect of Ocimum basilicum hydro-alcoholic extract on oxidative damage of brain tissue following seizures induced by pentylenetetrazole in mice, Physiology and Pharmacology, vol.21: 295-303

40. Krishnamurthy P, Wadhwani A (2012), Antioxidant enzymes and human health, Antioxidant enzyme, $1-17$

41. Kwon DY, Li X, Kim JK, Park SU (2019), Molecular cloning and characterization of rosmarinic acid biosynthetic genes and rosmarinic acid accumulation in Ocimum basilicum L, Saudi journal of biological sciences, vol.26: 469-472

42. Lee JH, Lee KT, Kim MR (2005), Effect of gamma-irradiated red pepper powder on the chemical and volatile characteristics of kakdugi, a Korean traditional fermented radish kimchi, Journal of food science, vol.70: c441-c447

43. Lemaire M, Silva LFN, Lemarie CA, Bolt AM, Molina MF, Krohn RM, Smits JE, Lehoux S, Mann KK (2015), Arsenic exposure increases monocyte adhesion to the vascular endothelium, a proatherogenic mechanism, PloS one, vol.10

44. Luo C, Zou L, Sun H, Peng J, Gao C, Bao L, Ji R, Jin Y, Sun S (2020), A Review of the AntiInflammatory Effects of Rosmarinic Acid on Inflammatory Diseases, Frontiers in Pharmacology, vol.11: 153

45. Maraei RW, Khaled M, Elsawy KM (2017) Chemical quality and nutrient composition of strawberry fruits treated by $Y$-irradiation. Journal of Radiation Research Applied Sciences 10::80-87

46. Mediratta P, Sharma K, Singh S (2002) Evaluation of immunomodulatory potential of Ocimum sanctum seed oil and its possible mechanism of action. Journal of Ethnopharmacology vol 80::1520

47. Medzhitov R (2010), Inflammation 2010: new adventures of an old flame, Cell, vol.140: 771-776 
48. Mochizuki H, Phyu KP, Aung MN, Zin PW, Yano Y, Myint MZ, Thit WM, Yamamoto Y, Hishikawa Y, Thant KZ (2019), Peripheral neuropathy induced by drinking water contaminated with low-dose arsenic in Myanmar, Environmental Health and Preventive Medicine, vol.24: 1-10

49. Mohammed ZI, Kadhim KS, Taher MG (2017) Effects of feeding different levels of ocimum basilicum seeds on per-formance and immune traits of broiler. Journal of Kerbala for Agricultural Sciences vol $4:: 249-258$

50. NCCIH (2018), Complementary, Alternative, or Integrative Health: What's In a Name?, From: https://nccih.nih.gov/health/integrative-health. Access date; 28 December, 2019

51. Nworgu F, Yekini B, Oduola O (2013) Effects of basil leaf (Ocimum gratissimum) supplement on some blood parameters of growing pullets. International Journal of Agriculture 3::480-488

52. Ofem O, Ani E, Eno A (2012) Effect of aqueous leaves extract of Ocimum gratissimum on hematological parameters in rats. International Journal of Applied Basic Medical Research 2::38-42

53. Osman NN, Ghazwani AH, Balamash KS (2020), Evaluation of the effect of gamma-irradiated Basil (Ocimum basilicum L.) on Liver Toxicity induced by Arsenic in Rats Journal of Radiation Research and Applied Sciences "in press\&\#8221

54. Pan S-Y, Litscher G, Gao S-H, Zhou S-F, Yu Z-L, Chen H-Q, Zhang S-F, Tang M-K, Sun J-N, Ko K-M (2014), Historical perspective of traditional indigenous medical practices: the current renaissance and conservation of herbal resources, Evidence-Based Complementary and Alternative Medicine, vol.2014: 20

55. Patel M, Gadhvi H, Patel S, Mankad A, Pandya H, Rawal R (2018) Holy basil: Holy herb to multimodal medicine for human health. The Pharma Innovation Journal 7::418-423

56. Pereira E, Pimenta Al, Barros L, Calhelha RC, Antonio AL, Verde SC, Ferreira IC (2018), Effects of gamma radiation on the bioactivity of medicinal and aromatic plants: Mentha $\times$ piperita L., Thymus vulgaris L. and Aloysia citrodora Paláu as case studies, Food \& function, vol.9: 5150-5161

57. Prasad P, Sinha D (2017), Low-level arsenic causes chronic inflammation and suppresses expression of phagocytic receptors, Environmental Science and Pollution Research, vol.24: 11708-11721

58. Primiano T, Sutter TR, Kensler TW (1997), Redox regulation of genes that protect against carcinogens, Comparative Biochemistry and Physiology Part B: Biochemistry and Molecular Biology, vol.118: 487-497

59. Rady AH, Toliba AO, Badr HM, Ali AK (2020), Impact of gamma radiation on antioxidant activity in faba bean (Vicia faba L.) and the potential of meatballs formulation with inclusion of the powder of irradiated beans, Journal of Food Science and Technology, 1-10

60. Ravindran $P$ (2017), The encyclopedia of herbs and spices: CABI

61. Rodrigues LB, Martins AOBPB, Cesário FRAS, Castro e, de Albuquerque FF, Fernandes TR, da Silva MNM, Júnior BAF, da Costa LJQ, J. G. M. and Coutinho HDM (2016), Anti-inflammatory and antiedematogenic activity of the Ocimum basilicum essential oil and its main compound estragole: in vivo mouse models, Chemico-biological interactions, vol.257: 14-25 
62. Rousselot P, Larghero J, Arnulf B, Poupon J, Royer B, Tibi A, Madelaine-Chambrin I, Cimerman P, Chevret S, Hermine $O$ (2004), A clinical and pharmacological study of arsenic trioxide in advanced multiple myeloma patients, Leukemia, vol.18: 1518-1521

63. SádECká J (2007) Irradiation of spices-a review. Czech Journal of Food Sciences vol 25::231-242

64. Saha S, Mukhopadhyay M, Ghosh P, Nath D (2012), Effect of methanolic leaf extract of Ocimum basilicum L. on benzene-induced hematotoxicity in mice, Evidence-Based Complementary and Alternative Medicine, vol.2012

65. Sakr SA, Al-Amoudi WM (2012) Effect of leave extract of Ocimum basilicum on deltamethrin induced nephrotoxicity and oxidative stress in albino rats. Journal of Applied Pharmaceutical Science 2:22

66. Sankar P, Telang AG, Suresh S, Kesavan M, Kannan K, Kalaivanan R, Sarkar SN (2013), Immunomodulatory effects of nanocurcumin in arsenic-exposed rats, International immunopharmacology, vol.17: 65-70

67. Shahidi F, Janitha P, Wanasundara P (1992), Phenolic antioxidants, Critical reviews in food science \& nutrition vol.32: 67-103

68. Shirazi MT, Gholami H, Kavoosi G, Rowshan V, Tafsiry A (2014), Chemical composition, antioxidant, antimicrobial and cytotoxic activities of $\mathrm{T}$ agetes minuta and $\mathrm{O}$ cimum basilicum essential oils, Food science \& nutrition, vol.2: 146-155

69. Sinclair RR, Wang M, Tetrick LE (2012) Research methods in occupational health psychology: Measurement, design, and data analysis. Routledge, New York

70. Singh V, Krishan P, Shri R (2018), Improvement of memory and neurological deficit with Ocimum basilicum L. extract after ischemia reperfusion induced cerebral injury in mice, Metabolic brain disease, vol.33: 1111-1120

71. Staff H (2019), Immunoglobulins, From: https://www.uofmhealth.org/health-library/hw41342. Access date; March 19, 2020

72. Su M, Sun C, Wang H, Yuan C, Guo R, Liang Y, Liu C, Wang Q (2018), Hematotoxicity of intratracheally instilled arsenic trioxide in rats, Infection International, vol.6: 32-40

73. Sumedha N, Miltonprabu S (2013) Arsenic induced oxidative hematotoxicity in rats and its protection by diallyl trisulfide. International Journal of Biological Pharmaceutical Research 4::507-515

74. Sun X, Li J, Zhao H, Wang Y, Liu J, Shao Y, Xue Y, Xing M (2018) Synergistic effect of copper and arsenic upon oxidative stress, inflammation and autophagy alterations in brain tissues of Gallus gallus. J Inorg Biochem 178:54-62

75. Taheri M, Mehrzad J, Afshari R, Saleh-Moghaddam M, Mahmudy Gharaie MH (2016) Inorganic arsenic can be potent granulotoxin in mammalian neutrophils in vitro. J Immunotoxicol 13:686-693

76. Takeuchi H, Takahashi-Muto C, Nagase M, Kassai M, Tanaka-Yachi R, Kiyose C (2020), Antiinflammatory Effects of Extracts of Sweet Basil (Ocimum basilicum L.) on a Co-culture of 3T3-L1 Adipocytes and RAW264. 7 Macrophages, Journal of Oleo Science, ess19321 
77. Tutkun L, Gunduzoz M, Turksoy VA, Deniz S, Oztan O, Cetintepe SP, Iritas SB, Yilmaz FM (2019) Arsenic-induced inflammation in workers. Mol Biol Rep 46::2371-2378

78. Villa G, Córdova A, Ávila C, Almar M, Marroyo J, García J, del Villar V (2003), Modificaciones de los leucocitos en ciclistas profesionales a lo largo de la competición, Revista clinica espanola, vol.203: $412-416$

79. Vimercati L, Gatti MF, Gagliardi T, Cuccaro F, De Maria L, Caputi A, Quarato M, Baldassarre A (2017), Environmental exposure to arsenic and chromium in an industrial area, Environmental Science and Pollution Research, vol.24: 11528-11535

80. Wen H-W, Chung H-P, Chou F-I, Lin I-h, Hsieh P-C (2006), Effect of gamma irradiation on microbial decontamination, and chemical and sensory characteristic of lycium fruit, Radiation Physics and Chemistry, vol.75: 596-603

81. Widjaja SS, Rusdiana MS (2019) Glucose Lowering Effect of Basil Leaves in Diabetic Rats. Open Access Macedonian Journal of Medical Sciences vol 7::1415-1417

82. Wu Y, Dai J, Zhang W, Yan R, Zhang Y, Ruan C, Dai K (2014), Arsenic trioxide induces apoptosis in human platelets via C-Jun NH2-terminal kinase activation, PloS one, vol.9

83. Zangeneh MM, Zangeneh A, Salmani S, Jamshidpour R, Kosari F (2019) Protection of phenylhydrazine-induced hematotoxicity by aqueous extract of Ocimum basilicum in Wistar male rats. Comparative Clinical Pathology vol 28::331-338

84. Zevallos-Concha A, Nuñez D, Gasco M, Vasquez C, Quispe M, Gonzales G (2016), Effect of gamma irradiation on phenol content, antioxidant activity and biological activity of black maca and red maca extracts (Lepidium meyenii walp), Toxicology mechanisms and methods, vol.26: 67-73

85. Zhao Y, Su X, Gao Y, Yin H, Wang L, Qiao R, Wang S (2019), Exposure of low-concentration arsenicinitiated inflammation and autophagy in rat lungs, Journal of biochemical and molecular toxicology, $1-7$

86. Zhou Y, Hong Y, Huang H (2016), Triptolide attenuates inflammatory response in membranous glomerulo-nephritis rat via downregulation of NF-kB signaling pathway, Kidney and Blood Pressure Research, vol.41: 901-910

\section{Figures}




\section{Total antioxidant}

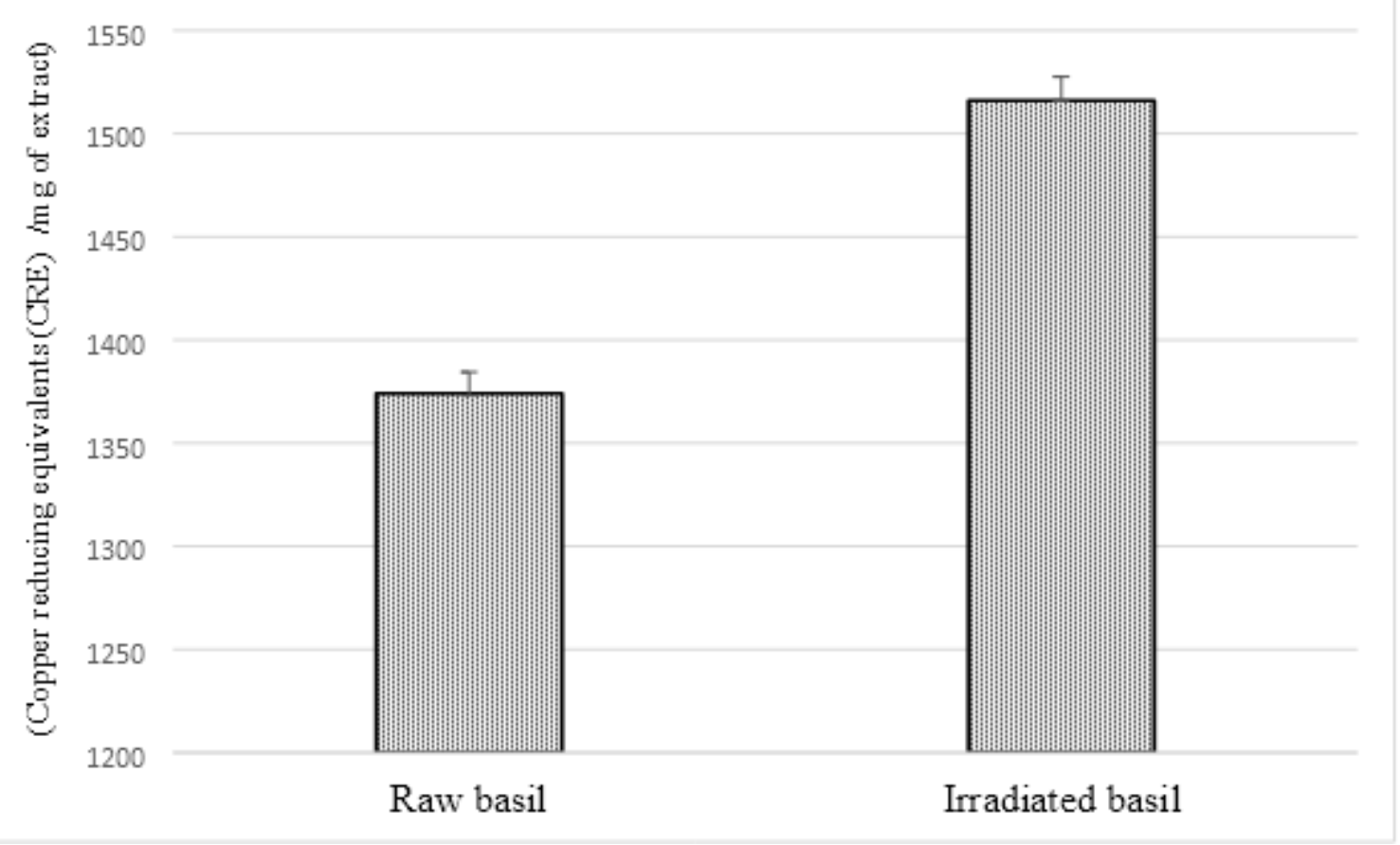

\section{Figure 1}

Total antioxidants in raw and irradiated basil

\section{Supplementary Files}

This is a list of supplementary files associated with this preprint. Click to download.

- Chapter4.pdf 